\title{
Activity and Stability of Trypsin Immobilized onto Chitosan Magnetic Nanoparticles
}

\author{
Jun Sun, Bin Xu, Yu Shi, Lin Yang, and Hai-le Ma \\ School of Food and Biological Engineering, Jiangsu University, Zhenjiang, Jiangsu 212013, China \\ Correspondence should be addressed to Hai-le Ma; 15181130@qq.com
}

Received 25 July 2016; Revised 2 September 2016; Accepted 24 October 2016; Published 22 January 2017

Academic Editor: Mikhael Bechelany

Copyright ( 2017 Jun Sun et al. This is an open access article distributed under the Creative Commons Attribution License, which permits unrestricted use, distribution, and reproduction in any medium, provided the original work is properly cited.

\begin{abstract}
The aim of this study was to develop a thermally and operationally stable trypsin through covalent immobilization onto chitosan magnetic nanoparticles $\left(\mathrm{Fe}_{3} \mathrm{O}_{4} @ \mathrm{CTS}\right)$. The successful preparation of the $\mathrm{Fe}_{3} \mathrm{O}_{4} @$ @TS nanoparticles was verified by Fourier transform infrared spectroscopy (FTIR), X-ray photoelectron spectroscopy (XPS), X-ray diffraction (XRD), and transmission electron microscopy (TEM), which indicated that the prepared $\mathrm{Fe}_{3} \mathrm{O}_{4} @ \mathrm{CTS}$ nanoparticles have superparamagnetic properties, with an average size of approximately $17 \mathrm{~nm}$. Then, trypsin was covalently immobilized onto the $\mathrm{Fe}_{3} \mathrm{O}_{4} @ \mathrm{CTS}$ nanoparticles at a high loading capacity $(149.25 \mathrm{mg} / \mathrm{g})$. The FTIR data demonstrated that the trypsin had undergone a conformational change compared with free trypsin, and the Michaelis constant $\left(K_{m}\right)$ and the maximum hydrolysis reaction rate $\left(V_{\max }\right)$ showed that the trypsin immobilized on the $\mathrm{Fe}_{3} \mathrm{O}_{4}$ @CTS had a lower affinity for BAEE and lower activity compared with free trypsin. However, the immobilized trypsin showed higher activity than free trypsin at $\mathrm{pH} 6.0$ and in alkaline conditions and retained more than $84 \%$ of its initial activity at $60^{\circ} \mathrm{C}$ after $8 \mathrm{~h}$ incubation. Its excellent performance across a broader $\mathrm{pH}$ range and high thermal stability, as well as its effective hydrolysis of bovine serum albumin (BSA) and its reusability, make it more attractive than free trypsin for application in protein digestion.
\end{abstract}

\section{Introduction}

Trypsin (E.C.3.2.1.17), which selectively hydrolyzes the arginine and lysine residues of proteins, is often used as a protein digestion reagent in food industry $[1,2]$. However, free trypsin suffers from a number of problems in practical applications, including a high expense, instability, and difficulties with its recovery from the reaction system. Furthermore, the digestion of proteins in solution is usually slow and inefficient because of the self-digestion of the trypsin [3]. To address these problems, the immobilization of the enzyme, leading to superior performance, has been widely investigated. An immobilized enzyme is one that is attached to a solid support, such as membranes [3], nanoparticles $[4,5]$, or porous materials $[6,7]$, through physical or chemical methods. The notable advantages of immobilization include improved enzyme stability, ease of isolation from the protein digestion solutions, and the possibility of repeated use $[8,9]$. Among the most widely reported enzyme carriers, $\mathrm{Fe}_{3} \mathrm{O}_{4}$ magnetic nanoparticles, which allow the products to be easily separated from the mixture, have attracted interest for their biological compatibility [10]. However, because of the weak interactions between the enzyme and the $\mathrm{Fe}_{3} \mathrm{O}_{4}$ magnetic nanoparticles, the use of naked $\mathrm{Fe}_{3} \mathrm{O}_{4}$ nanoparticles for trypsin immobilization leads to low loading and instability of the enzyme. By modification of the $\mathrm{Fe}_{3} \mathrm{O}_{4}$ nanoparticles, not only can their stability be improved, but also the efficiency of enzyme immobilization.

Chitosan (CTS) is a renewable resource, which is second only to cellulose in natural abundance, and biocompatible, biodegradable, and nontoxic [11, 12], more suitable for application in food. In addition, CTS has a significant affinity for proteins because of the highly active interface formed by the hydroxyl and amino groups in CTS molecules. Therefore, CTS has broad application prospects in the field of enzyme immobilization.

In our previous study, we reported a novel and facile method for the application of carboxymethyl CTS magnetic nanoparticles as a new class of nanocarriers for trypsin immobilization through physical adsorption [13]. However, 
the results indicated that the immobilized trypsin prepared by physical adsorption was easily detached from the carriers, which hindered its practical application in complex system of food.

To date, there have been many studies of trypsin immobilization, most of which have aimed at enhancing the efficiency and activity of the immobilized trypsin. However, being thermally and operationally stable is also crucial for promoting the industrialization of immobilized trypsin. Hence, in this study, the surface decoration of $\mathrm{Fe}_{3} \mathrm{O}_{4}$ nanoparticles by CTS and their subsequent application for trypsin immobilization were achieved through glutaraldehyde coupling, which was found to prevent enzyme loss from the support and enhance the stability and reusability of the trypsin. The synthesized CTS magnetic nanoparticles $\left(\mathrm{Fe}_{3} \mathrm{O}_{4} @ \mathrm{CTS}\right)$ were characterized by FTIR, XPS, XRD, and TEM in terms of their specific functional groups, crystal structure, and surface morphology. For the immobilized trypsin, its conformation, kinetic properties, response to $\mathrm{pH}$, and thermal stability, as well as its applicability and reusability for protein digestion, were evaluated in detail.

\section{Materials and Methods}

2.1. Materials. $N$ - $\alpha$-Benzoyl-1-arginine ethyl ester (BAEE) and trypsin (TPCK (tosyl phenylalanyl chloromethyl ketone) treated trypsin) were purchased from Sigma-Aldrich Co., USA: chitosan (CTS), iron(II) sulfate heptahydrate $\left(\mathrm{FeSO}_{4} \cdot 7 \mathrm{H}_{2} \mathrm{O}\right), \quad 25 \%$ ammonia solution $\left(\mathrm{NH}_{3} \cdot \mathrm{H}_{2} \mathrm{O}\right)$, iron(III) chloride hexahydrate $\left(\mathrm{FeCl}_{3} \cdot 6 \mathrm{H}_{2} \mathrm{O}\right)$, ammonium bicarbonate $\left(\mathrm{NH}_{4} \mathrm{HCO}_{3}\right)$, acetic acid, glutaraldehyde, liquid paraffin, Tween-80, magnesium stearate, ethyl ether, acetone, ethanol, bovine serum albumin (BSA), and pure water (with an electrical resistivity of $18.2 \mathrm{M} \Omega \mathrm{cm}$ ).

2.2. Fabrication of Chitosan Magnetic Nanoparticles. CTS magnetic nanoparticles $\left(\mathrm{Fe}_{3} \mathrm{O}_{4} @ \mathrm{CTS}\right)$ were prepared by two steps. Firstly, naked $\mathrm{Fe}_{3} \mathrm{O}_{4}$ nanoparticles were synthesized by the chemical coprecipitation $\mathrm{FeSO}_{4} \cdot 7 \mathrm{H}_{2} \mathrm{O}$ and $\mathrm{FeCl}_{3} \cdot 6 \mathrm{H}_{2} \mathrm{O}$ (molar ratio was $3: 2$ ) in $\mathrm{NH}_{3} \cdot \mathrm{H}_{2} \mathrm{O}$ solution followed by treating in nitrogen condition for $1 \mathrm{~h}$ at $80^{\circ} \mathrm{C}$.

Next, the $\mathrm{Fe}_{3} \mathrm{O}_{4}$ @CTS were prepared by the emulsion crosslinking method, following the procedure developed by Zhao et al. with some modifications [14]. Firstly, $160 \mathrm{~mL}$ of liquid paraffin, $12 \mathrm{~mL}$ of Tween-80, and $0.1 \mathrm{~mL}$ of magnesium stearate were added into $1 \mathrm{~L}$ three-necked bottles under continuous stirring. Secondly, $0.6 \mathrm{~g}$ of CTS and $1.2 \mathrm{~g}$ of $\mathrm{Fe}_{3} \mathrm{O}_{4}$ magnetic nanoparticles were dissolved in $40 \mathrm{~mL}$ of $1.5 \%(\mathrm{v} / \mathrm{v})$ acetic acid solution under ultrasonic dispersion for $2 \mathrm{~h}$, then added into the above solution, and left to react for $1 \mathrm{~h}$ at $40^{\circ} \mathrm{C}$. Thirdly, $20 \mathrm{~mL}$ of $5 \%(\mathrm{v} / \mathrm{v})$ glutaraldehyde solution was added to the above solution and left to react for $1 \mathrm{~h}$; then, the $\mathrm{pH}$ of the reaction medium was adjusted to above 10 using $\mathrm{NH}_{3} \cdot \mathrm{H}_{2} \mathrm{O}$ solution and left for $60 \mathrm{~min}$ at $60^{\circ} \mathrm{C}$. Finally, the synthesized magnetic nanoparticles were gathered by a magnet and rinsed with ether, acetone, ethanol, and distilled water in sequence to remove the unreacted chemical reagents. Finally, the collected precipitate $\left(\mathrm{Fe}_{3} \mathrm{O}_{4} @ \mathrm{CTS}\right)$ was freezedried for approximately $48 \mathrm{~h}$.
2.3. Characterization of Magnetic Nanoparticles. FTIR spectroscopy (Nicolet is50, Thermo Electron Corporation) was used to confirm the synthesis of $\mathrm{Fe}_{3} \mathrm{O}_{4}$ @CTS. The freezedried powder of $\mathrm{Fe}_{3} \mathrm{O}_{4}, \mathrm{Fe}_{3} \mathrm{O}_{4}$ @CTS, and CTS were grounded and used for analysis. FTIR was performed by attenuated total reflectance using atmosphere as background over the range of 4000 to $525 \mathrm{~cm}^{-1}$.

X-ray photoelectron spectroscopy (XPS, ESCALAB 250Xi, Thermo Fisher Scientific Corporation) was recorded using a Sigma Probe (Thermo VG, UK) photoelectron spectrometer, Pass Energy 30.0 Ev, Energy Step Size: $0.100 \mathrm{eV}$.

The crystalline structures of the naked $\mathrm{Fe}_{3} \mathrm{O}_{4}$ and $\mathrm{Fe}_{3} \mathrm{O}_{4}$ @CTS nanoparticles were investigated with XRD. The XRD pattern of the product was performed on an D8 ADVANCE $\mathrm{X}$-Ray diffractometer with $\mathrm{Cu}-\mathrm{Ka}$ radiation with a scan range of approximately $20^{\circ} \mathrm{C}$ to $80^{\circ} \mathrm{C}$ at a rate of $5^{\circ} \mathrm{C} \mathrm{min}{ }^{-1}$.

Morphologic analysis of the $\mathrm{Fe}_{3} \mathrm{O}_{4}$ before and after modification was performed with TEM (Tecnai 12, Philips). The samples were prepared by placing two drops of nanoparticle alcoholic solution on a carbon-coated copper grid and dried for detection.

\subsection{Covalent Immobilization of Trypsin}

2.4.1. Activation of $\mathrm{Fe}_{3} \mathrm{O}_{4}$ @CTS Nanoparticles. $10 \mathrm{mg}$ of $\mathrm{Fe}_{3} \mathrm{O}_{4} @$ @TS was mixed with $50 \mu \mathrm{L}$ of a $0.5 \%$ solution of glutaraldehyde in water and $2 \mathrm{~mL}$ of phosphate buffer solution (PBS, $20 \mathrm{mmol} / \mathrm{L}, \mathrm{pH} 7.5)$ and was shaken $(200 \mathrm{rpm})$ for $1 \mathrm{~h}$ at $25^{\circ} \mathrm{C}$. The activated $\mathrm{Fe}_{3} \mathrm{O}_{4} @ \mathrm{CTS}$ were then gathered and washed three times with $3 \mathrm{~mL}$ of PBS. Finally, the activated $\mathrm{Fe}_{3} \mathrm{O}_{4} @$ @TS NPs were redispersed in $3 \mathrm{~mL}$ of PBS (20 mmol/L, pH 7.5).

2.4.2. Covalent Immobilization of Trypsin. The above activated $\mathrm{Fe}_{3} \mathrm{O}_{4}$ @CTS solution was mixed with $1 \mathrm{mg} / \mathrm{mL}$ of trypsin solution, and the mixed solution was shaken at $160 \mathrm{rpm}$ at room temperature for $30-120 \mathrm{~min}$. After the immobilization, the trypsin immobilized on $\mathrm{Fe}_{3} \mathrm{O}_{4}$ @CTS was collected by a magnet and then washed four times with $3 \mathrm{~mL}$ of PBS. The trypsin concentrations before and after immobilization on the $\mathrm{Fe}_{3} \mathrm{O}_{4}$ @CTS in the buffer solution were determined from their absorbance at $280 \mathrm{~nm}$.

2.5. Trypsin Activity Assay. The bioactivity of the free and immobilized trypsin was detected by the method of Schwert and Takenaka with some modifications [15]. The blank solution contained $2.8 \mathrm{~mL}$ of $1 \mathrm{mM}$ BAEE in $25 \mathrm{mM}$ of $\mathrm{NH}_{4} \mathrm{HCO}_{3}$ buffer solution ( $\mathrm{pH}$ 8) and $0.2 \mathrm{~mL}$ of $1 \mathrm{mM} \mathrm{HCl}$, and the test solution contained $2.8 \mathrm{~mL}$ of $1 \mathrm{mM}$ BAEE solution and $0.2 \mathrm{~mL}$ of immobilized trypsin $(1 \mathrm{mg} / \mathrm{mL})$. The absorbance at $253 \mathrm{~nm}$ was measured every $30 \mathrm{~s}$ for $4 \mathrm{~min}$ at $25^{\circ} \mathrm{C}$. The step-by-step assay procedures for trypsin bioactivity can be found in our previous study [13].

The activity was calculated with the following equations:

$$
\begin{aligned}
& \text { Activity (BAEE unit } / \mathrm{mL})=\frac{\Delta A 253 \mathrm{~nm} / \mathrm{min}}{0.001 \times V(\text { trypsin })}, \\
& \text { Activity (BAEE unit/mg) } \\
& =\frac{\text { Activity (BAEE unit } / \mathrm{mL})}{\text { concentration of trypsin }(\mathrm{mg} / \mathrm{mL}) \times V(\text { trypsin })} .
\end{aligned}
$$


In the case of native trypsin, the activity measurement was performed following similar procedures and conditions to those for immobilized trypsin.

2.6. Optimal $p H$ for Trypsin Activity. The optimum $\mathrm{pH}$ of the free and immobilized trypsin was studied over a $\mathrm{pH}$ range of 6-9.6. The enzyme assay was carried out with the substrate prepared in buffer solutions of varying $\mathrm{pH}: 20 \mathrm{mmol} / \mathrm{L} \mathrm{PBS}$ for $\mathrm{pH} 6.0$ and 7.0; $20 \mathrm{mmol} / \mathrm{L} \mathrm{NH}_{4} \mathrm{HCO}_{3}$ buffer solution for $\mathrm{pH}$ 8.0; $20 \mathrm{mmol} / \mathrm{L}$ boric acid-borax buffer solution for $\mathrm{pH}$ 8.4 and 9.0; and $20 \mathrm{mmol} / \mathrm{L}$ borax- $\mathrm{NaOH}$ buffer solution for $\mathrm{pH}$ 9.6. The reaction mixtures were incubated at $25^{\circ} \mathrm{C}$ for the enzyme assay, and the optimal activities for immobilized and free trypsin were taken as $100 \%$.

2.7. Thermal Stability. The thermal stabilities of trypsin in its free and immobilized states were evaluated by measuring the residual activity at $60^{\circ} \mathrm{C}$ in BAEE buffer solution $(\mathrm{pH}$ $8,20 \mathrm{mmol} / \mathrm{L}, \mathrm{NH}_{4} \mathrm{HCO}_{3}$ ). The residual trypsin activity was measured at varying periods of time $(2,4,6$, and $8 \mathrm{~h})$. The free and immobilized trypsin without incubation was assigned a relative activity of $100 \%$.

2.8. Digestion of BSA Using Immobilized Trypsin. Bovine serum albumin (BSA; $10 \mathrm{mg}$ in $2 \mathrm{~mL}$ of $25 \mathrm{mM} \mathrm{NH}_{4} \mathrm{HCO}_{3}$ buffer solution $(\mathrm{pH} 8)$ ) was denatured in a $95^{\circ} \mathrm{C}$ water bath for $15 \mathrm{~min}$. Then, $5 \mathrm{mg}$ of immobilized trypsin was added into the above denatured BSA solution. After incubation at $37^{\circ} \mathrm{C}$ for $15 \mathrm{~min}$, the immobilized trypsin was collected under an external magnetic field, and the separated supernatant was characterized by reversed-phase high-performance liquid chromatography (RP-HPLC) at room temperature. RP-HPLC was performed using an Agilent Pursuit5 C18 $(250 \times 4.6 \mathrm{~mm})$ with the following mobile phases: eluent $\mathrm{A}\left(\mathrm{TFA} / \mathrm{H}_{2} \mathrm{O}\right)$ was composed of $0.02 \%(\mathrm{v} / \mathrm{v})$ trifluoroacetic acid (TFA) in highly pure water, and eluent B (TFA/ACN) was composed of $0.02 \%(\mathrm{v} / \mathrm{v})$ TFA in (acetonitrile) ACN solution. The gradient elution of eluent B proceeded as follows: $20 \%$ for $5 \mathrm{~min}$, then from $20 \%$ to $30 \%$ at $10 \mathrm{~min}, 30-40 \%$ at $20 \mathrm{~min}, 40-$ $50 \%$ at $30 \mathrm{~min}$, and $50-60 \%$ at $40 \mathrm{~min}$, with a flow rate of $0.5 \mathrm{~mL} / \mathrm{min}$, injection volume of $10 \mu \mathrm{L}$, and wavelength of $214 \mathrm{~nm}$.

2.9. Reusability. The reusability of the immobilized trypsin was evaluated for BAEE hydrolysis at $25^{\circ} \mathrm{C}$. After each cycle of enzymolysis, the immobilized trypsin was collected and washed several times with $\mathrm{pH} 8 \mathrm{NH}_{4} \mathrm{HCO}_{3}$ buffer solution $(25 \mathrm{mmol} / \mathrm{L})$, and then a new run was started in the same buffer solution. The immobilized trypsin before the first cycle was assigned a relative activity of $100 \%$.

\section{Results and Discussion}

3.1. Magnetic Nanoparticles: Characterization. CTS is naturally abundant, biocompatible, biodegradable, and harmless to the environment. Furthermore, the hydroxyl and amino groups in the CTS molecule can form a highly active interface, so the compound has a significant affinity for enzymes via ionic bonds, hydrogen bonds, covalent bonds, and van der

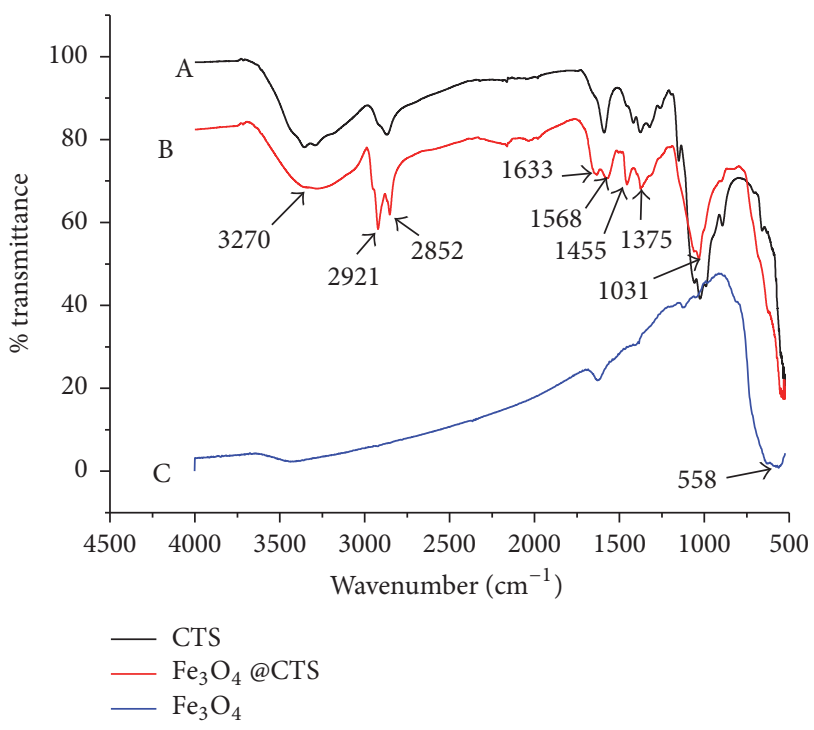

FIgURE 1: FTIR spectra of CTS (A), $\mathrm{Fe}_{3} \mathrm{O}_{4} @ \mathrm{CTS}(\mathrm{B})$, and naked $\mathrm{Fe}_{3} \mathrm{O}_{4}(\mathrm{C})$.

Waals forces. Hence, the modification of functional magnetic nanoparticles by CTS and their subsequent use for enzyme immobilization has attracted much attention. In this paper, functional $\mathrm{Fe}_{3} \mathrm{O}_{4} @$ @CTS particles were prepared by modification of naked $\mathrm{Fe}_{3} \mathrm{O}_{4}$ nanoparticles by CTS via covalent chemical bonding and then used for trypsin immobilization and subsequently for protein digestion (Scheme 1).

3.1.1. FTIR. Determining the unknown functional groups of compounds is an important application of FTIR. Thus, the naked $\mathrm{Fe}_{3} \mathrm{O}_{4}$ particles modified by CTS were characterized by FTIR, as shown in Figure 1. Figure 1(A) shows the characteristic peaks of CTS $(-\mathrm{OH}$ stretching vibration at $3270 \mathrm{~cm}^{-1}$; $-\mathrm{CH}$ stretching vibrations at 2921 and $2852 \mathrm{~cm}^{-1}$; $\mathrm{N}-\mathrm{H}$ stretching vibration at $1558 \mathrm{~cm}^{-1}$; $-\mathrm{CN}$ stretching vibrations at 1455 and $1375 \mathrm{~cm}^{-1}$; and antisymmetric vibrations of $\mathrm{C}-\mathrm{O}-\mathrm{C}$ at $1034 \mathrm{~cm}^{-1}$ ), while Figure $1(\mathrm{C})$ shows the spectrum of naked $\mathrm{Fe}_{3} \mathrm{O}_{4}$, with the stretching of $\mathrm{Fe}-\mathrm{O}$ bonds at $558 \mathrm{~cm}^{-1}$. As can be seen, all of these peaks were also detected in the spectrum of $\mathrm{Fe}_{3} \mathrm{O}_{4}$ @CTS (Figure 1(B)), together with the characteristic peaks at $1633 \mathrm{~cm}^{-1}$ due to the $\mathrm{CHO}$ groups of glutaraldehyde. Therefore, the above results indicate that CTS was successfully bound on the surface of the $\mathrm{Fe}_{3} \mathrm{O}_{4}$ nanoparticles through the glutaraldehyde emulsion crosslinking method.

3.1.2. XPS. The XPS spectra of naked $\mathrm{Fe}_{3} \mathrm{O}_{4}$ and the $\mathrm{Fe}_{3} \mathrm{O}_{4}$ @CTS nanoparticles are shown in Figure 2. The main characteristic peaks at 711.8 and $724.6 \mathrm{eV}$ correspond to $\mathrm{Fe} 2 \mathrm{p}_{3 / 2}$ and $\mathrm{Fe} 2 \mathrm{p}_{1 / 2}$, respectively; these two characteristic peaks are consistent with the XPS spectra of $\mathrm{Fe}_{3} \mathrm{O}_{4}$ reported in previous research [16]. This demonstrates that the $\mathrm{Fe}_{3} \mathrm{O}_{4}$ nanoparticles were synthesized successfully. Furthermore, CTS contains the elements $\mathrm{N}$ and $\mathrm{C}$. The characteristic peaks of Fe2p (712.3 eV), N1s (400.16 eV), and C1s $(286.91 \mathrm{eV})$ also appeared 

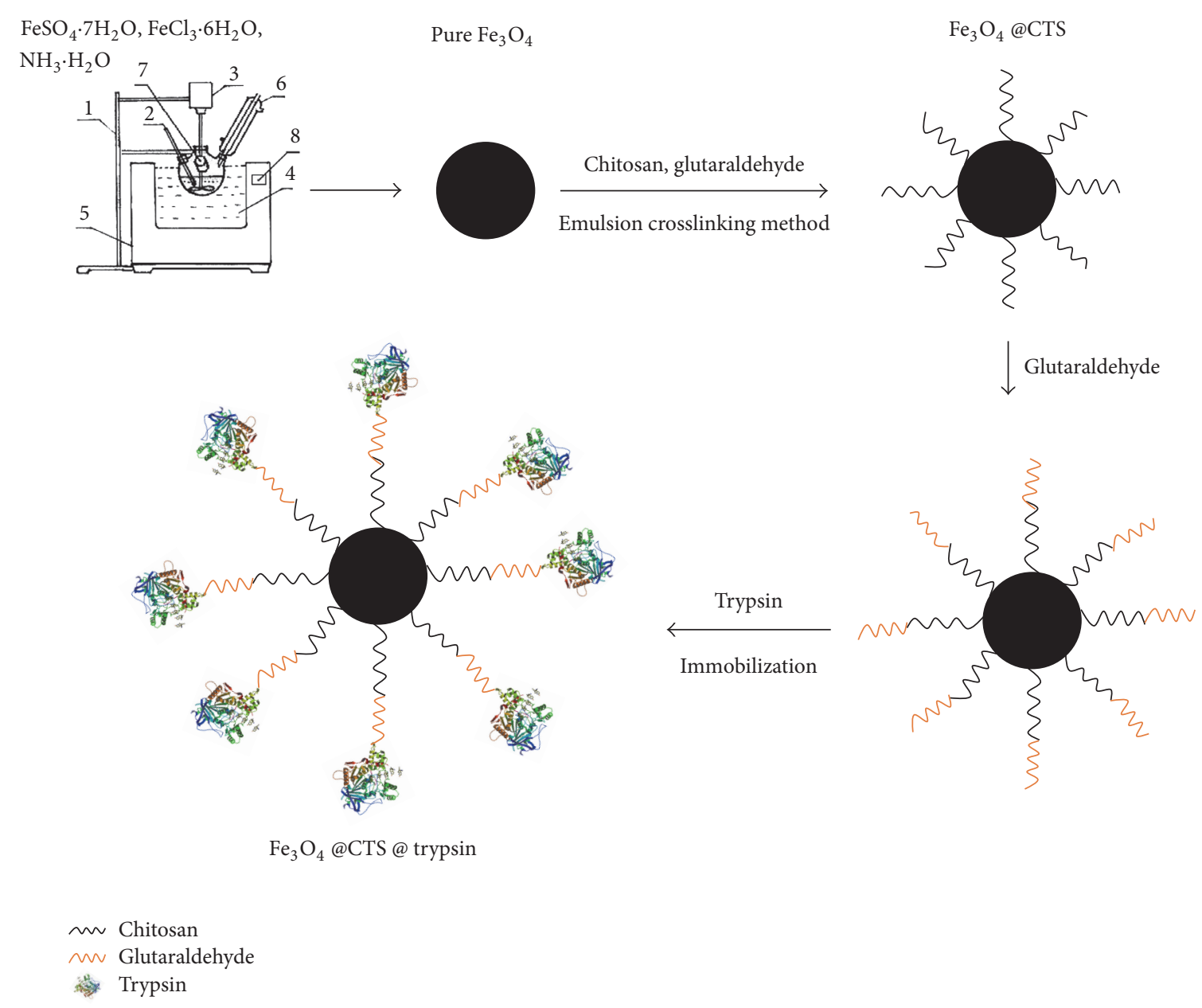

$\downarrow$ Glutaraldehyde

SCHEME 1: The procedure to prepare chitosan magnetic nanoparticles for trypsin immobilization.

in the $\mathrm{Fe}_{3} \mathrm{O}_{4} @ \mathrm{CTS}$ spectrum, with a small shift, indicating that the CTS was indeed encapsulated within the $\mathrm{Fe}_{3} \mathrm{O}_{4}$ nanoparticles, consistent with the conclusions of FTIR.

3.1.3. XRD and TEM Images. Each crystalline material has a unique chemical composition and crystal structure. In this study, the crystalline structures of the naked $\mathrm{Fe}_{3} \mathrm{O}_{4}$ and $\mathrm{Fe}_{3} \mathrm{O}_{4}$ @CTS nanoparticles were investigated using XRD (Figure 3 ). Figure 3(A) displays the XRD patterns of the naked $\mathrm{Fe}_{3} \mathrm{O}_{4}$ : the six characteristic peaks, which occur at $2 \theta$ values of $29.7^{\circ}$, $35.2^{\circ}, 42.5^{\circ}, 52.4^{\circ}, 56.3^{\circ}$, and $62.2^{\circ}$, are labeled with their corresponding indices, that is, (220), (311), (400), (422), (511), and (440), respectively. These six characteristic peaks are consistent with the entry for $\mathrm{Fe}_{3} \mathrm{O}_{4}$ in the JCPDS database (PDF no. 65-3107), while no peaks associated with other crystal structures are evident. This indicates that the synthesized naked $\mathrm{Fe}_{3} \mathrm{O}_{4}$ nanoparticles adopted a spinel structure. Furthermore, for the $\mathrm{Fe}_{3} \mathrm{O}_{4}$ @CTS nanoparticles, the same six characteristic peaks were also observed. This indicates that the coating process did not result in a phase change of $\mathrm{Fe}_{3} \mathrm{O}_{4}$, implying that the $\mathrm{Fe}_{3} \mathrm{O}_{4}$ @CTS particles preserved their magnetic properties during the separation process.
The morphologies of the $\mathrm{Fe}_{3} \mathrm{O}_{4}$ before and after modification with CTS are shown in Figure 4. The image indicates that both $\mathrm{Fe}_{3} \mathrm{O}_{4}$ (a) and the functionalized $\mathrm{Fe}_{3} \mathrm{O}_{4}$ @CTS nanoparticles (b) were spherical in shape and uniformly distributed. The $\mathrm{Fe}_{3} \mathrm{O}_{4} @ \mathrm{CTS}$ nanoparticles had an average size of approximately $17 \mathrm{~nm}$, slightly larger than that of the naked particles (approximately $13 \mathrm{~nm}$ ). It is known that magnetic particles less than approximately $25 \mathrm{~nm}$ in size exhibit superparamagnetism [17]. Therefore, the prepared $\mathrm{Fe}_{3} \mathrm{O}_{4}$ and $\mathrm{Fe}_{3} \mathrm{O}_{4} @ \mathrm{CTS}$ nanoparticles had superparamagnetic properties and could be efficiently used for enzyme immobilization and separation.

According to the principle of crystal growth dynamics, the nucleation of nanocrystals proceeds by growth in the direction with the lowest energy. Therefore, at low concentration and with a long enough reaction time, all of the nanocrystals will grow in the morphology and direction with the lowest chemical potential, which will lead to the formation of spherical nanoparticles. For this reason, minimizing the concentration is the key to obtaining spherically uniform $\mathrm{Fe}_{3} \mathrm{O}_{4}$ and $\mathrm{Fe}_{3} \mathrm{O}_{4} @ \mathrm{CTS}$ nanoparticles. Furthermore, the $\mathrm{pH}$ stability of the $\mathrm{Fe}_{3} \mathrm{O}_{4}$ @CTS nanoparticles was improved 

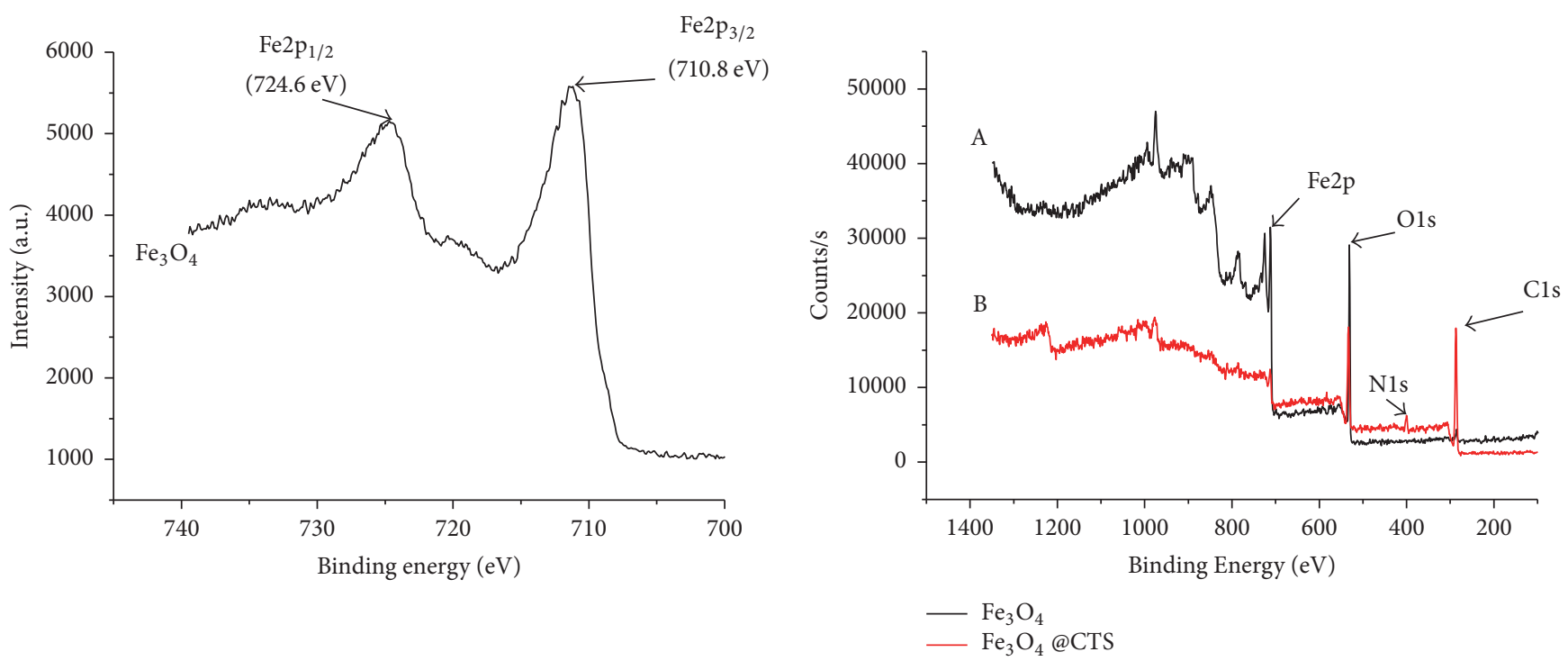

Figure 2: XPS spectra of $\mathrm{Fe}_{3} \mathrm{O}_{4}(\mathrm{~A})$ and $\mathrm{Fe}_{3} \mathrm{O}_{4}$ @CTS (B).

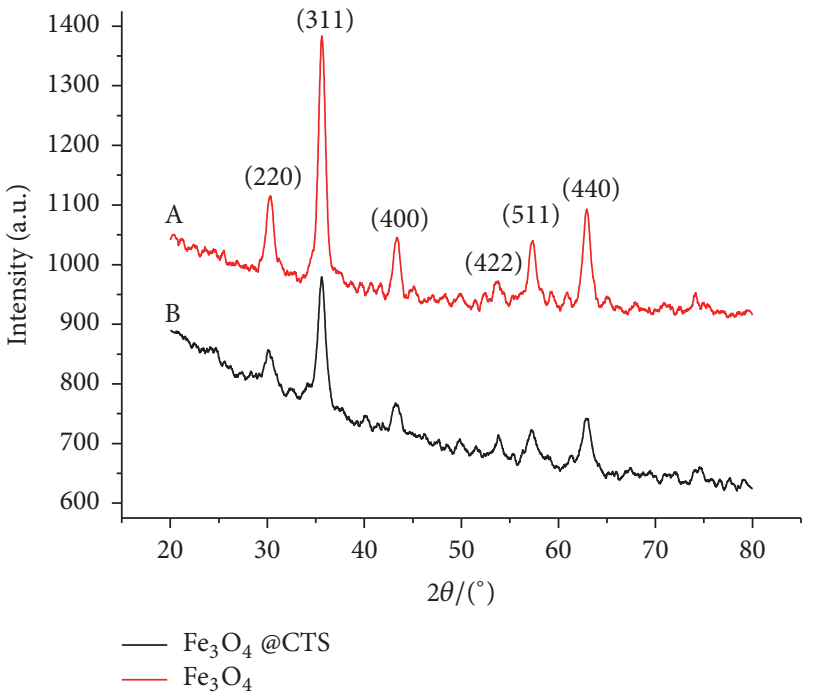

Figure 3: XRD spectrum of $\mathrm{Fe}_{3} \mathrm{O}_{4}(\mathrm{~A})$ and $\mathrm{Fe}_{3} \mathrm{O}_{4} @ \mathrm{CTS}(\mathrm{B})$.

through glutaraldehyde crosslinking, stabilizing the particles for use in further study and applications.

3.2. Trypsin Immobilization Results. Trypsin is one of the most popular enzymes for protein hydrolysis, but it is not stable in its free state. Hence, in this research, the trypsin was irreversibly immobilized onto the amino-functionalized $\mathrm{Fe}_{3} \mathrm{O}_{4} @ \mathrm{CTS}$ nanoparticles through covalent bonding with glutaraldehyde. The glutaraldehyde acted as an aminoconnecting arm, reacting with amine groups both on the surface of the $\mathrm{Fe}_{3} \mathrm{O}_{4}$ @CTS nanoparticles and in trypsin, thus fixing the trypsin onto the surface of the $\mathrm{Fe}_{3} \mathrm{O}_{4} @ \mathrm{CTS}$ nanoparticles through covalent chemical bonds. The concentration of glutaraldehyde has a significant effect on the activity of the immobilized trypsin; pilot experiments showed that the highest enzyme activity was obtained with a glutaraldehyde concentration of $0.5 \%(\mathrm{v} / \mathrm{v})$.

3.2.1. FTIR. In this study, trypsin was immobilized onto the $\mathrm{Fe}_{3} \mathrm{O}_{4} @ \mathrm{CTS}$ nanoparticles via glutaraldehyde crosslinking. Figure 5 shows the FTIR spectra of the $\mathrm{Fe}_{3} \mathrm{O}_{4} @ \mathrm{CTS}$ nanoparticles, free trypsin, and the trypsin immobilized on the surface of $\mathrm{Fe}_{3} \mathrm{O}_{4}$ @CTS. It can be seen that the spectrum of trypsin after immobilization on the $\mathrm{Fe}_{3} \mathrm{O}_{4} @ \mathrm{CTS}$ nanoparticles (Figure 5(B)) shows not only the characteristic peaks of $\mathrm{C}=\mathrm{N}$ at $1647 \mathrm{~cm}^{-1}$, which were formed from the amino groups of trypsin and the aldehyde groups of the glutaraldehyde-activated $\mathrm{Fe}_{3} \mathrm{O}_{4}$ @CTS nanoparticles, but also the characteristic bands of the $\mathrm{Fe}_{3} \mathrm{O}_{4}$ @CTS nanoparticles, which are at $558 \mathrm{~cm}^{-1}(\mathrm{Fe}=\mathrm{O}), 2921$ and $2852 \mathrm{~cm}^{-1}(\mathrm{C}-$ $\mathrm{H}$, stretching vibration), 1455 and $1375 \mathrm{~cm}^{-1}$ (C-N, stretching vibration), and $1034 \mathrm{~cm}^{-1}$ (C-O-C, antisymmetric vibrations) (Figure 5(C)). These peaks indicated that the trypsin was successfully immobilized onto the surface of the $\mathrm{Fe}_{3} \mathrm{O}_{4}$ @CTS nanoparticles through glutaraldehyde crosslinking.

3.2.2. Secondary Structure of Immobilized Trypsin. The activity of an enzyme is closely related to its conformation, so maintaining a stable enzyme conformation during immobilization is essential. Hence, the conformational change of trypsin after immobilization on the functionalized $\mathrm{Fe}_{3} \mathrm{O}_{4}$ @CTS was analyzed. Compared with the free trypsin, the band shape and peak position in the range of $1600-1700 \mathrm{~cm}^{-1}$ in the spectrum of immobilized trypsin are very different (Supplementary Material, Figure 1) (see Supplementary Material available online at https://doi.org/10.1155/2017/ 1457072), indicating a distinct conformational change of trypsin during immobilization. In addition, the secondary structural elements of free and immobilized trypsin were analyzed and calculated using PeakFit v4.12 (Figure 6). As can be seen, the $\alpha$-helix content showed a clear increase 


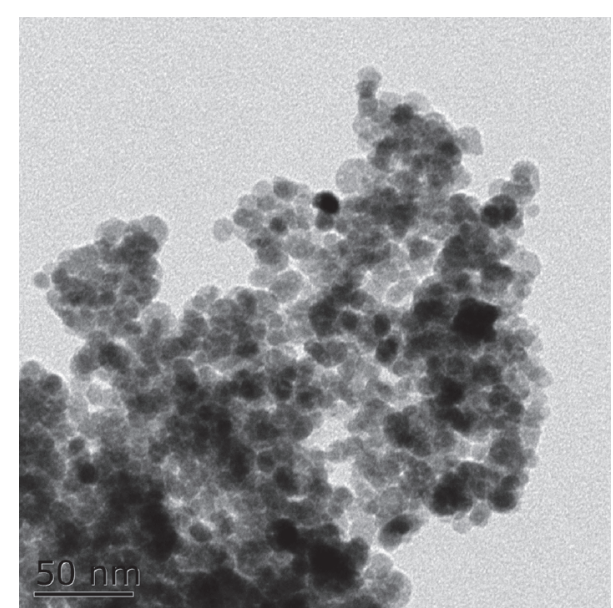

(a)

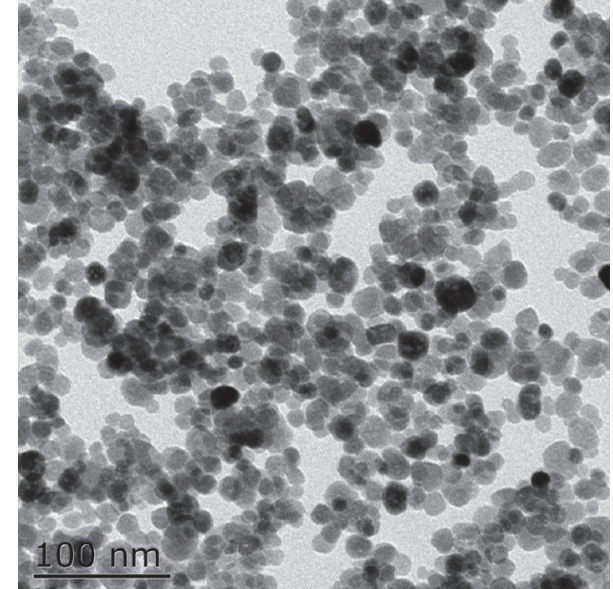

(b)

FIGURE 4: TEM micrographs of naked $\mathrm{Fe}_{3} \mathrm{O}_{4}$ before (a) and after (b) coating with CTS.

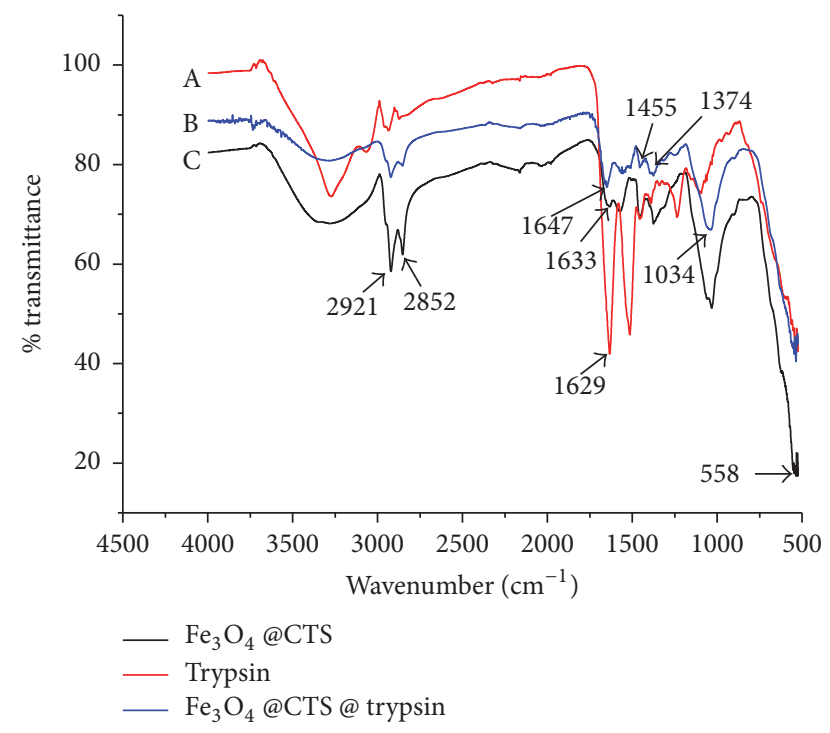

FIgURE 5: FTIR spectra of trypsin (A), $\mathrm{Fe}_{3} \mathrm{O}_{4} @ \mathrm{CTS} @ \operatorname{trypsin}(\mathrm{B})$, and $\mathrm{Fe}_{3} \mathrm{O}_{4} @ \mathrm{CTS}(\mathrm{C})$.

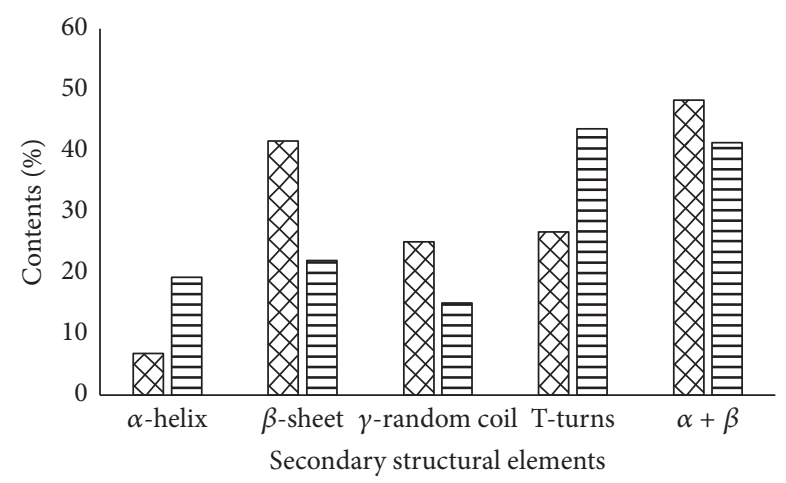

Free trypsin

曰 Immobilized trypsin

FIGURE 6: Secondary structural contents of free trypsin and immobilized trypsin determined by FTIR spectroscopy. from $6.8 \%$ to $19.3 \%$, while the contents of $\beta$-sheet and $\gamma$-random coil showed clear decreases of $19.5 \%$ and $10 \%$. However, the decrease in the total content of $\alpha+\beta$ was only $7.0 \%$, indicating that, although the trypsin immobilized on the surface of the $\mathrm{Fe}_{3} \mathrm{O}_{4} @$ CTS nanoparticles underwent a conformational change compared with free trypsin, the overall conformational state remained relatively compact.

3.2.3. Kinetics of Trypsin Immobilization on $\mathrm{Fe}_{3} \mathrm{O}_{4} @ \mathrm{CTS}$ Nanoparticles. The effect of immobilization time on trypsin loading was tested at room temperature with initial trypsin concentration $1 \mathrm{mg} / \mathrm{g}$, as shown in Figure 7(a). As can be seen, the trypsin loading increased rapidly during the first $30 \mathrm{~min}$, after which the increasing trend became relatively slow. This indicated the high efficiency of trypsin immobilization on the $\mathrm{Fe}_{3} \mathrm{O}_{4} @ \mathrm{CTS}$ nanoparticles, due to their characteristics of small diameter and large specific surface area.

The data obtained were analyzed using the Lagergren pseudo-first-order and pseudo-second-order kinetic models. The Lagergren pseudo-first-order model is expressed as follows [18]:

$$
\frac{1}{q_{t}}=\frac{k_{1}}{q_{e} t}+\frac{1}{q_{e}},
$$

where $q_{e}$ is the maximum enzyme loading for Lagergren pseudo-first-order kinetics ( $\mathrm{mg} / \mathrm{g}$ ), $q_{t}$ is the enzyme loading at time $t(\mathrm{mg} / \mathrm{g}), k_{1}$ is the Lagergren pseudo-first-order rate constant $\left(\mathrm{min}^{-1}\right)$, and $t$ is the immobilization time.

The value of $1 / q_{t}$ was plotted versus $1 / t$ according to the Lagergren pseudo-first-order model.

The Lagergren pseudo-second-order kinetic model is expressed by the following equation [19]:

$$
\frac{t}{q_{t}}=\frac{t}{q_{e}}+\frac{1}{k_{2} \times q_{e}^{2}},
$$

where $k_{2}$ is the Lagergren pseudo-second-order kinetic rate constant $\left(\mathrm{min}^{-1}\right)$.

The value of $t / q_{t}$ was plotted versus $t$ according to the Lagergren pseudo-second-order kinetic model. 


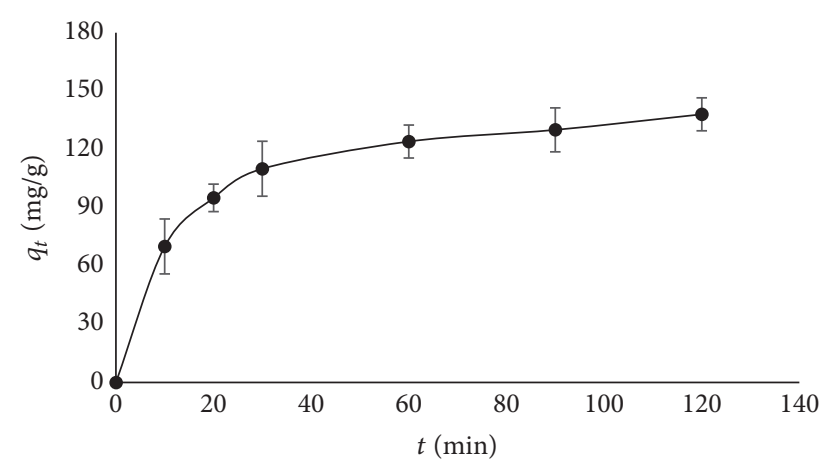

(a)

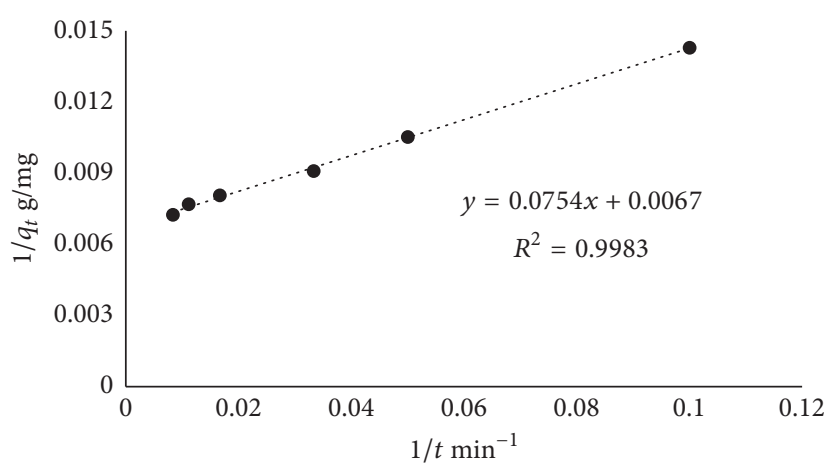

(b)

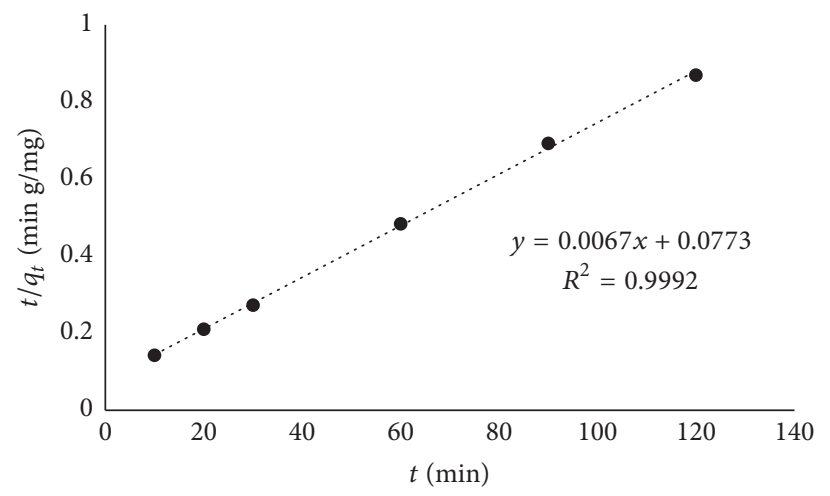

(c)

Figure 7: (a) Effect of immobilization time to trypsin loading; kinetic models of enzyme immobilization; (b) Lagergren pseudo-first-order kinetics, the linear plot of $1 / q_{t}$ versus $1 / t$; (c) Lagergren pseudo-second-order kinetics, the linear plot of $t / q_{t}$ versus $t$.

The fitting curves of the Lagergren pseudo-first-order and pseudo-second-order kinetic models are shown in Figures $7(\mathrm{~b})$ and $7(\mathrm{c})$. As can be seen, the correlation coefficient $\left(R^{2}\right)$ of the pseudo-second-order model is higher than that of the pseudo-first-order model, indicating that the pseudosecond-order kinetic model is more suitable for fitting these experimental data, and hence the immobilization of trypsin may be a complex process of both physical and chemical adsorption. According to the equation $y=0.0067 x+0.0773$, the maximum trypsin loading of the $\mathrm{Fe}_{3} \mathrm{O}_{4} @$ @CTS nanoparticles was $149.25 \mathrm{mg} / \mathrm{g}$ under the experimental conditions (trypsin concentration $1 \mathrm{mg} / \mathrm{g}$ ) which is higher than that reported in some earlier research $[20,21]$.

3.2.4. Activity Evaluation of Immobilized Trypsin. A more accurate assessment of the activity changes of trypsin after immobilization was performed by examining the Michaelis constant $\left(K_{m}\right)$ and the maximum hydrolysis reaction rate $\left(V_{\max }\right)$ of trypsin before and after immobilization on the surface of $\mathrm{Fe}_{3} \mathrm{O}_{4} @$ @CTS nanoparticles. The experimental conditions were as follows: BAEE was used as the substrate at various concentrations from 0.5 to $10 \mathrm{mmol} / \mathrm{L}$, and the trypsin activity was evaluated at $25^{\circ} \mathrm{C}$ and $\mathrm{pH} 8.0$ in the presence of free or immobilized trypsin. The Lineweaver-Burk equation, shown below, was used to evaluate the $K_{m}$ of trypsin:

$$
\frac{1}{V}=\frac{1}{V_{\max }}+\left(\frac{K_{m}}{V_{\max }}\right) \frac{1}{[S]}
$$

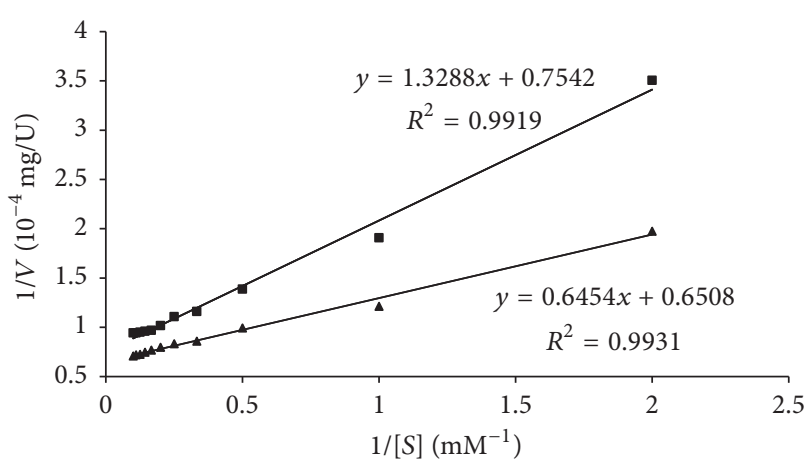

FIGURE 8: Lineweaver-Burk plots for the hydrolysis of BAEE as the substrate in the presence of free trypsin $(\mathbf{\Delta})$ and immobilized trypsin (घ).

where $[S]$ is the substrate concentration, $V$ is the hydrolysis reaction rate, $K_{m}$ is the Michaelis constant, and $V_{\max }$ is the maximum hydrolysis reaction rate.

The value of $1 /[S]$ was plotted versus $1 / V$ according to the Lineweaver-Burk equation.

As shown in Figure 8, these plots displayed a good linear relationship and could thus be used to evaluate $K_{m}$ and $V_{\max }$. According to the Lineweaver-Burk equation, the calculated value of $K_{m}$ was $1.76 \mathrm{mM}$, which was higher than that of free trypsin $(0.99 \mathrm{mM})$. This indicates that the trypsin immobilized on the $\mathrm{Fe}_{3} \mathrm{O}_{4}$ @CTS had a lower affinity for 


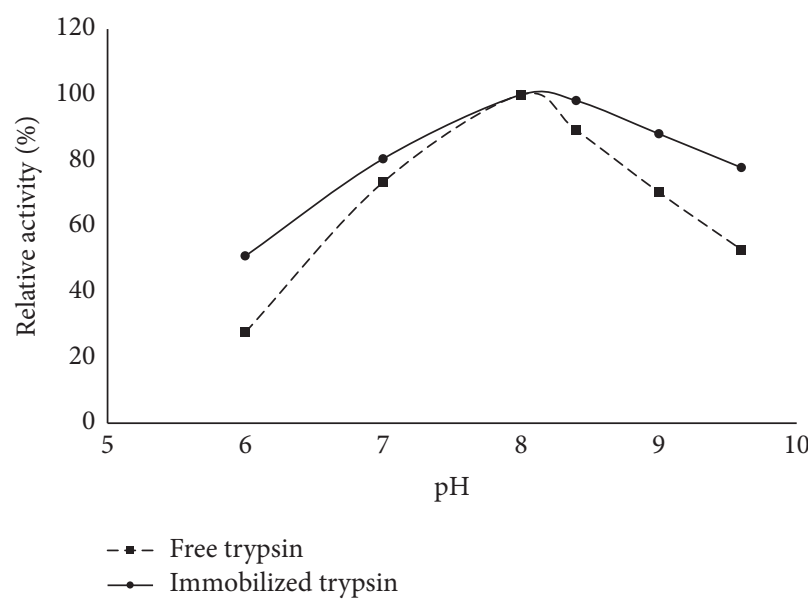

(a)

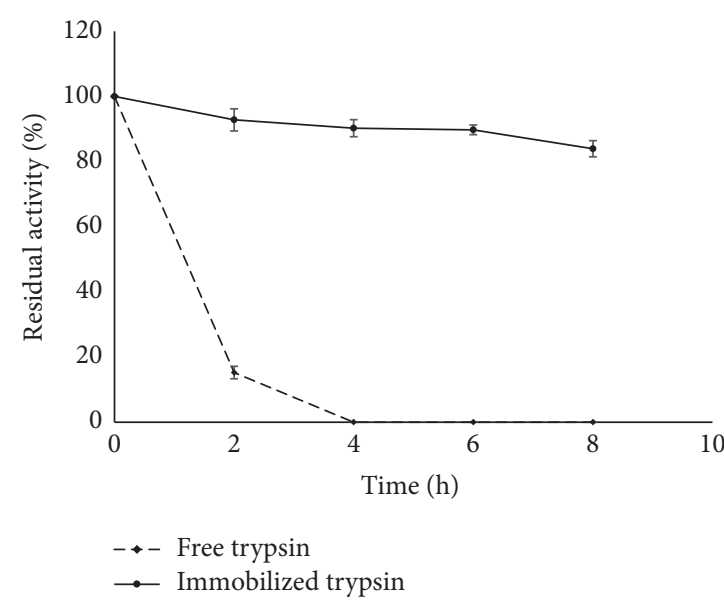

(b)

FIGURE 9: (a) Effects of $\mathrm{pH}$ on activity of free trypsin and immobilized trypsin. (b) Thermal stability studies of free and immobilized trypsin.

BAEE, possibly due to the blocking effect of the $\mathrm{Fe}_{3} \mathrm{O}_{4}$ @CTS carriers, which reduces the contact area between the immobilized enzyme and the substrate. Furthermore, $V_{\max }$ of the free and immobilized enzymes were found to be 1.5366 and $1.3259 \mu \mathrm{mol} \mathrm{L}^{-1} \mathrm{~min}^{-1}$, respectively, suggesting that the immobilization of the enzyme resulted in lower activity compared with the free trypsin. However, the increased enzyme loading was sufficient to offset the conformational change of the trypsin.

3.3. Effects of $p H$ on the Enzyme Activity. The variation of $\mathrm{pH}$ in the reaction medium can affect the stability of the enzyme and, consequently, its activity [14]. Hence, in this research, the effects of reaction $\mathrm{pH}$ on the activities of immobilized trypsin were studied and compared with those for the free trypsin. As can be seen, both free and immobilized trypsin had their highest activities at $\mathrm{pH} 8$, which is the "optimum $\mathrm{pH}^{\text {" value }}$ of trypsin (Figure 9(a)). However, it can also be seen from the figure that the immobilized trypsin showed higher activities than the free trypsin both at $\mathrm{pH} 6.0$ and in alkaline conditions, similarly to previous results reported in the literature $[5,22]$. Possibly, the covalent interaction between the $\mathrm{Fe}_{3} \mathrm{O}_{4}$ @CTS nanoparticles and trypsin increased the rigidity of the trypsin molecules, inhibiting the extensional distortion and nonspecific aggregation of the trypsin molecules, thus allowing them to better resist the effect of $\mathrm{pH}$ change.

3.4. Thermal Stability. Because enzymes are generally sensitive to heat, enhanced thermal stability is among the most important properties of immobilized enzymes for applications. The thermal stability of the immobilized trypsin was measured in comparison with that of free trypsin. The results showed that the thermal stability of the trypsin immobilized on $\mathrm{Fe}_{3} \mathrm{O}_{4} @ \mathrm{CTS}$ nanoparticles was improved compared with that of the free trypsin at $60^{\circ} \mathrm{C}$ (Figure 9(b)). The free trypsin lost almost all of its activity at $60^{\circ} \mathrm{C}$ after $4 \mathrm{~h}$ of incubation, whereas the immobilized trypsin retained more than $84 \%$ of its initial activity after $8 \mathrm{~h}$ of incubation. The high temperature resistance and enhanced thermal stability of the immobilized trypsin may be the result of the covalently bound system, which prevented the conformational denaturation of the enzyme at higher temperatures, making it more heat-resistant than the soluble form.

In addition, to ensure that the activity losses during the thermal stability experiment are not due to the leaching of trypsin from the $\mathrm{Fe}_{3} \mathrm{O}_{4} @$ @CTS nanoparticles surface, the stock solutions of immobilized trypsin were determined from their absorbance at $280 \mathrm{~nm}$, and the results indicated that there is no trypsin detected in those immobilized trypsin stocks' solution.

3.5. BSA Hydrolysis. Trypsin is commonly used for protein digestion in the food industry, but because of its instability and difficulties with its recovery from the reaction solution, its application is limited. In contrast, immobilized trypsin has attracted extensive interest because of its advantages, such as ease of separation from the solution, greatly reduced digestion time, and greatly enhanced enzyme stability. In this research, BSA was used as a model protein to evaluate the activity of the immobilized trypsin, as shown in Figure 10. The results showed that the trypsin immobilized on the surface of $\mathrm{Fe}_{3} \mathrm{O}_{4} @ \mathrm{CTS}$ was capable of efficient BSA hydrolysis: nearly all of the BSA was hydrolyzed under the studied experimental conditions.

3.6. Reusability. The operational stability of immobilized enzymes is crucial. Thus, in the present research, the reusability of the immobilized trypsin was evaluated by using the same batch of immobilized trypsin for repeated activity assays. The results showed that although the activity of the immobilized trypsin decreased as the number of reuse cycles increased, the immobilized trypsin nonetheless retained a residual activity of $82.3 \%$ after six cycles (Figure 11). Thus, the prepared trypsin, immobilized by covalent chemical bonds, had excellent operational stability for continuous hydrolysis. Evidently, the covalent bonding of trypsin to the $\mathrm{Fe}_{3} \mathrm{O}_{4}$ $@$ @CTS nanoparticles acted to enhance its conformational stability. In addition, the loss of activity of the immobilized 


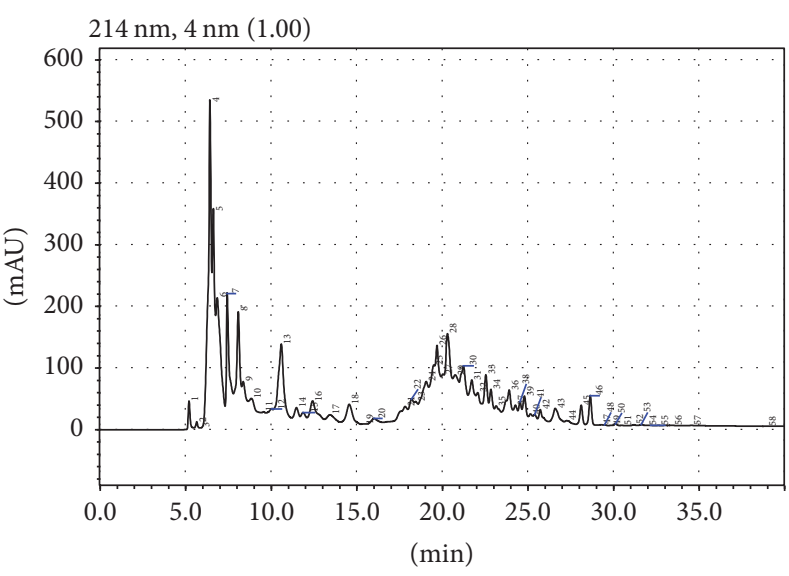

(a)

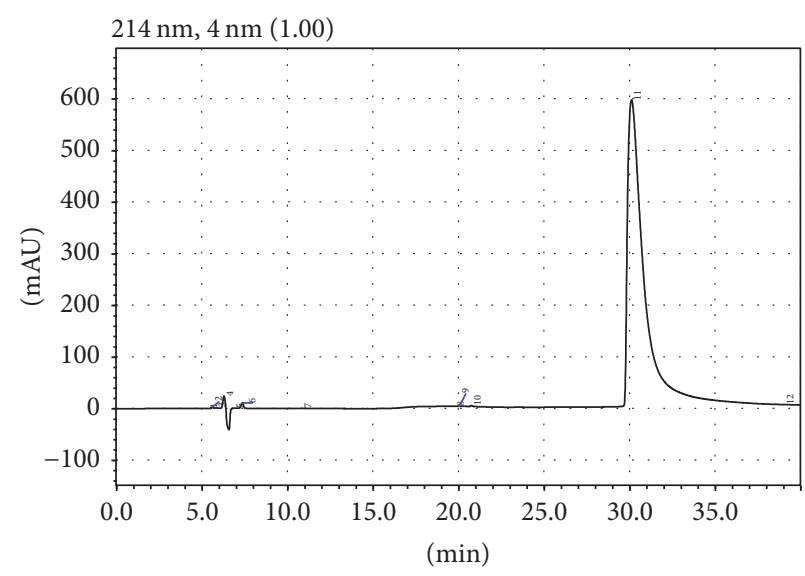

(b)

FIGURE 10: Reverse-phase HPLC: (a) immobilized trypsin hydrolysis products and (b) the BSA.

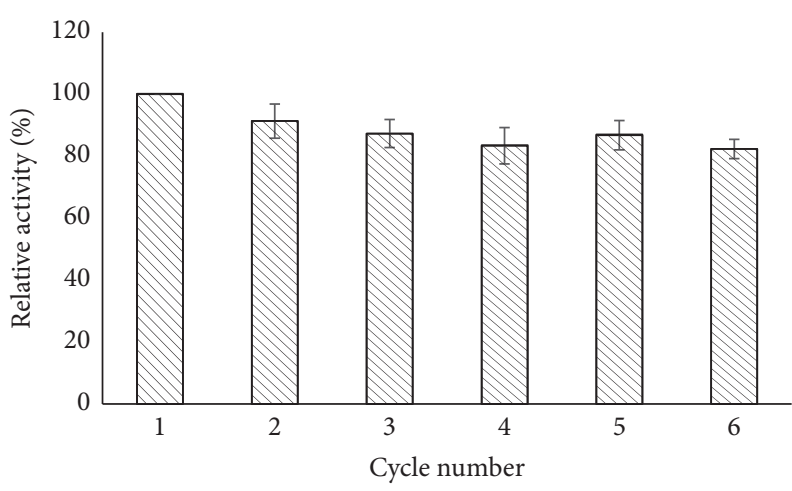

FiguRE 11: Reusability of immobilized trypsin.

trypsin can arise both from the inactivation and from the loss of trypsin during repeated use. However, because the immobilized trypsin possessed greater stability during reuse compared with the free trypsin, the decrease in its activity was offset by the ability of the trypsin immobilized on $\mathrm{Fe}_{3} \mathrm{O}_{4}$ @CTS nanoparticles to be reused.

\section{Conclusion}

Magnetic $\mathrm{Fe}_{3} \mathrm{O}_{4}$ @CTS nanoparticles were prepared by chemical coprecipitation and emulsion crosslinking and successfully applied to the immobilization of trypsin through covalent chemical bonding. The synthesized $\mathrm{Fe}_{3} \mathrm{O}_{4} @ \mathrm{CTS}$ nanoparticles were characterized by FTIR, XPS, XRD, and TEM, which revealed that CTS had been successfully grafted onto the $\mathrm{Fe}_{3} \mathrm{O}_{4}$ nanoparticles and that the $\mathrm{Fe}_{3} \mathrm{O}_{4}$ @CTS nanoparticles were spherical in shape and uniformly distributed, with an average size of approximately $17 \mathrm{~nm}$. The successful conjugation of trypsin with the $\mathrm{Fe}_{3} \mathrm{O}_{4}$ @CTS nanoparticles was confirmed by FTIR spectroscopy and enzymatic assay; furthermore, changes in the optimal $\mathrm{pH}$ and the kinetic constants were observed, possibly resulting from the conformational change of trypsin during immobilization. However, the improved thermal stability and excellent reusability of the $\mathrm{Fe}_{3} \mathrm{O}_{4}$ @CTS nanoparticles illustrate the potential of this system of trypsin immobilized on $\mathrm{Fe}_{3} \mathrm{O}_{4}$ @CTS nanoparticles for enzyme hydrolysis.

\section{Competing Interests}

The authors declare that they have no competing interests.

\section{Acknowledgments}

Authors express sincere thanks to the Youth Nature Science Foundation of Jiangsu (BK20130491), China Postdoctoral Science Foundation Funded Project (2013M531288), Natural Science Research of University in Jiangsu Province (13KJB550005), and the Senior Talent Scientific Research Founds of Jiangsu University (12JDG077) for supporting this work.

\section{References}

[1] C. S. Zhou, X. Yu, X. P. Qin, H. L. Ma, A. E. A. Yagoub, and J. L. Hu, "Hydrolysis of rapeseed meal protein under simulated duodenum digestion: kinetic modeling and antioxidant activity," LWT-Food Science and Technology, vol. 68, pp. 523-531, 2016.

[2] C.-F. Chi, B. Wang, Y.-Y. Deng, Y.-M. Wang, S.-G. Deng, and J.-Y. Ma, "Isolation and characterization of three antioxidant pentapeptides from protein hydrolysate of monkfish (Lophius litulon) muscle," Food Research International, vol. 55, pp. 222228, 2014.

[3] T. R. Silva, D. P. Rodrigues, J. M. S. Rocha et al., "Immobilization of trypsin onto poly(ethylene terephthalate)/poly(lactic acid) nonwoven nanofiber mats," Biochemical Engineering Journal, vol. 104, pp. 48-56, 2015.

[4] M. L. Verma, R. Chaudhary, T. Tsuzuki, C. J. Barrow, and M. Puri, "Immobilization of $\beta$-glucosidase on a magnetic nanoparticle improves thermostability: application in cellobiose hydrolysis," Bioresource Technology, vol. 135, pp. 2-6, 2013.

[5] J. N. Talbert and J. M. Goddard, "Characterization of lactaseconjugated magnetic nanoparticles," Process Biochemistry, vol. 48, no. 4, pp. 656-662, 2013. 
[6] C. Bernal, A. Illanes, and L. Wilson, "Heterofunctional hydrophilic-hydrophobic porous silica as support for multipoint covalent immobilization of lipases: application to lactulose palmitate synthesis," Langmuir, vol. 30, no. 12, pp. 35573566, 2014.

[7] W. J. Goh, V. S. Makam, J. Hu et al., "Iron oxide filled magnetic carbon nanotube-enzyme conjugates for recycling of amyloglucosidase: toward useful applications in biofuel production process," Langmuir, vol. 28, no. 49, pp. 16864-16873, 2012.

[8] D. Goradia, J. Cooney, B. K. Hodnett, and E. Magner, "The adsorption characteristics, activity and stability of trypsin onto mesoporous silicates," Journal of Molecular Catalysis B: Enzymatic, vol. 32, no. 5-6, pp. 231-239, 2005.

[9] C.-G. Liu, K. G. H. Desai, X.-G. Chen, and H.-J. Park, "Preparation and characterization of nanoparticles containing trypsin based on hydrophobically modified chitosan," Journal of Agricultural and Food Chemistry, vol. 53, no. 5, pp. 1728-1733, 2005.

[10] M. Jain, P. Radha, S. Kiruthika, C. Muthukumaran, and K. Tamilarasan, "Synthesis, characterization and kinetic analysis of chitosan coated magnetic nanobiocatalyst and its application on glucose oleate ester synthesis," Journal of Molecular Catalysis B: Enzymatic, vol. 128, pp. 1-9, 2016.

[11] B. Krajewska, "Application of chitin- and chitosan-based materials for enzyme immobilizations: a review," Enzyme and Microbial Technology, vol. 35, no. 2-3, pp. 126-139, 2004.

[12] J. Wang, L. Wang, H. Yu et al., "Recent progress on synthesis, property and application of modified chitosan: an overview," International Journal of Biological Macromolecules, vol. 88, pp. 333-344, 2016.

[13] J. Sun, K. Y. Hu, Y. T. Liu, Y. J. Pan, and Y. J. Yang, "Novel superparamagnetic sanoparticles for trypsin immobilization and the application for efficient proteolysis," Journal of Chromatography B, vol. 942-943, pp. 9-14, 2013.

[14] D.-L. Zhao, X.-X. Wang, X.-W. Zeng, Q.-S. Xia, and J.-T. Tang, "Preparation and inductive heating property of $\mathrm{Fe}_{3} \mathrm{O}_{4}$-chitosan composite nanoparticles in an AC magnetic field for localized hyperthermia," Journal of Alloys and Compounds, vol. 477, no. 1-2, pp. 739-743, 2009.

[15] G. W. Schwert and Y. Takenaka, "A spectrophotometric determination of trypsin and chymotrypsin," Biochimica et Biophysica Acta, vol. 16, pp. 570-575, 1955.

[16] Z. G. Peng, K. Hidajat, and M. S. Uddin, "Adsorption of bovine serum albumin on nanosized magnetic particles," Journal of Colloid and Interface Science, vol. 271, no. 2, pp. 277-283, 2004.

[17] J. Lee, T. Isobe, and M. Senna, "Preparation of ultrafine $\mathrm{Fe}_{3} \mathrm{O}_{4}$ particles by precipitation in the presence of PVA at high $\mathrm{pH}$," Journal of Colloid and Interface Science, vol. 177, no. 2, pp. 490494, 1996.

[18] M. Odabaşi, R. Say, and A. Denizli, "Molecular imprinted particles for lysozyme purification," Materials Science and Engineering C, vol. 27, no. 1, pp. 90-99, 2007.

[19] N. Başar, L. Uzun, A. Güner, and A. Denizli, "Lysozyme purification with dye-affinity beads under magnetic field," International Journal of Biological Macromolecules, vol. 41, no. 3, pp. 234-242, 2007.

[20] Y. Li, X. Xu, C. Deng, P. Yang, and X. Zhang, "Immobilization of trypsin on superparamagnetic nanoparticles for rapid and effective proteolysis," Journal of Proteome Research, vol. 6, no. 9, pp. 3849-3855, 2007.
[21] Y. Deng, C. Deng, D. Qi et al., "Synthesis of core/shell colloidal magnetic zeolite microspheres for the immobilization of trypsin," Advanced Materials, vol. 21, no. 13, pp. 1377-1382, 2009.

[22] A. Hill, D. Irvine, and D. Bullock, "Precipitation and recovery of whey proteins: a review," Canadian Institute of Food Science and Technology Journal, vol. 15, no. 3, pp. 155-160, 1982. 

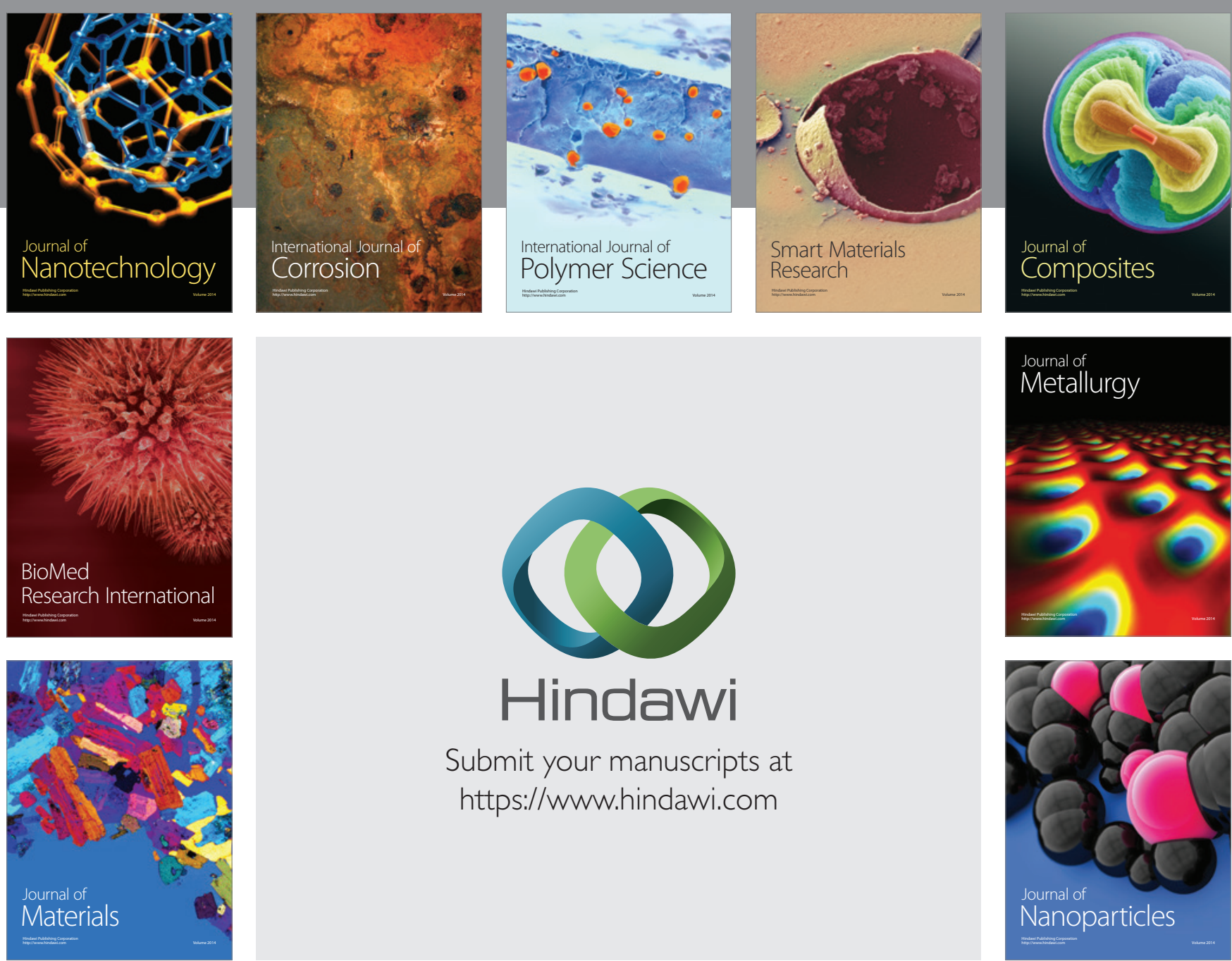

\section{Hindawi}

Submit your manuscripts at

https://www.hindawi.com

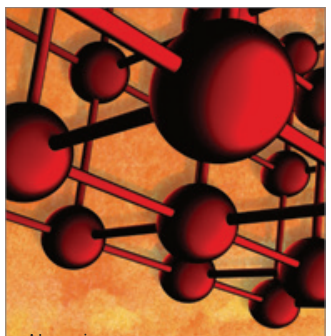

Materials Science and Engineering
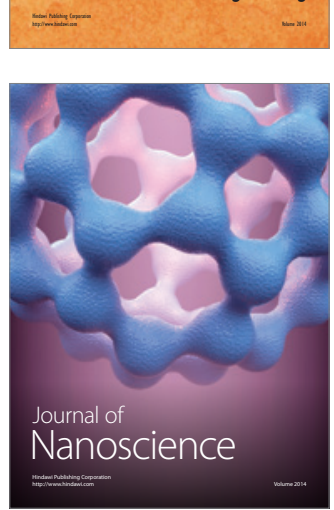
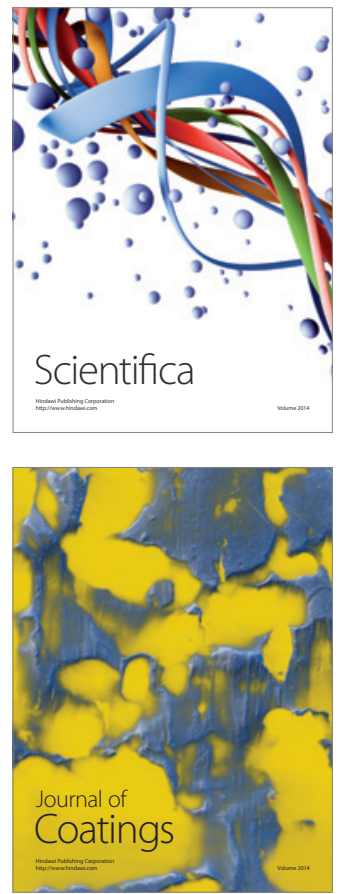
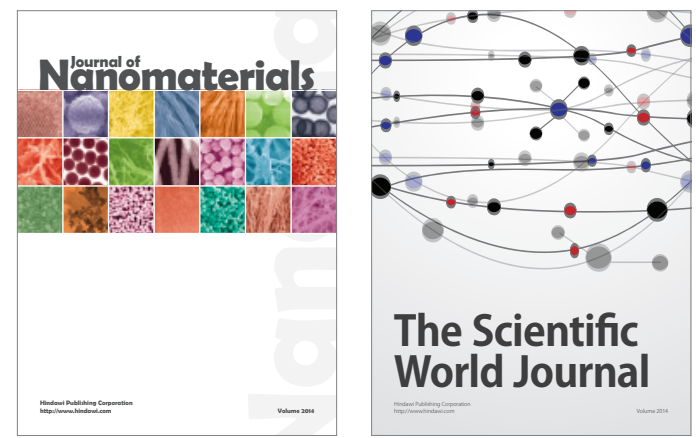

The Scientific World Journal
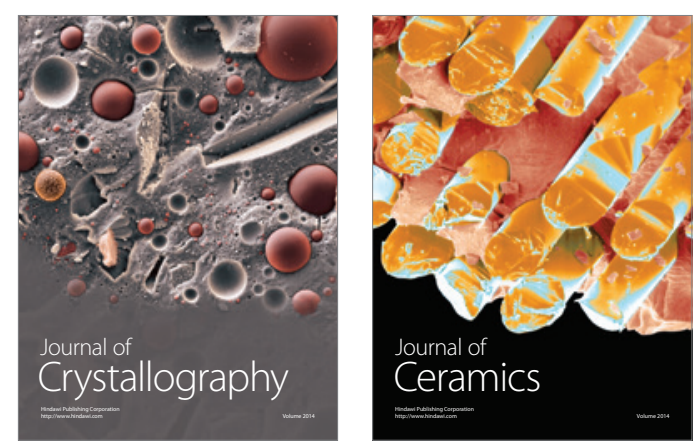
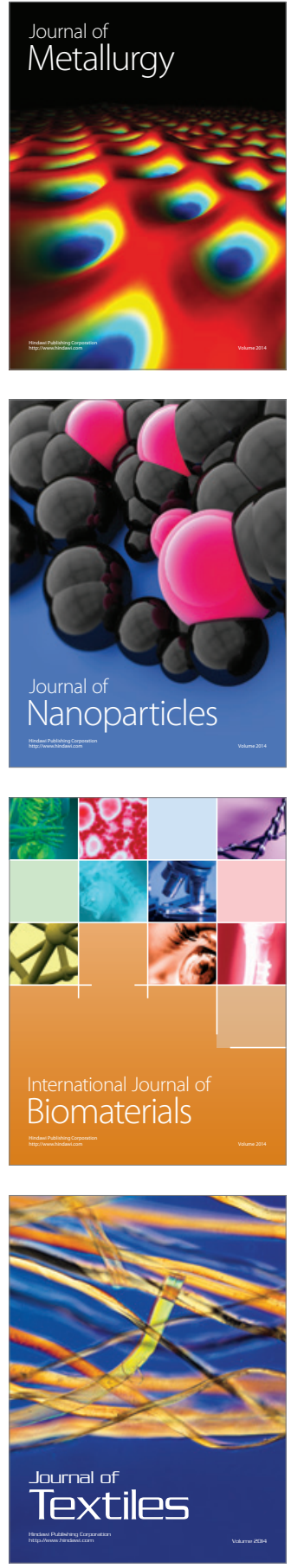